\title{
An Insight into the Well-being of Primary School-Aged Children
}

\author{
Anastasia Miliffe
}

\begin{abstract}
The child well-being movement seeks to enhance the well-being of all children and protect our most vulnerable. The plethora of definitions and approaches to child well-being may create ambiguity and uncertainty about what child well-being means and what researchbased frameworks are available to support it. In this initial study, the well-being views of primary schoolaged children were explored and aligned with the Developmental Assets approach which conceptualises child well-being in terms of the relationships, opportunities, competencies, values and self-perceptions that all youth need to be resilient and thrive (Search Institute, 2012). The results highlight the importance of interests to subjective child well-being and the limited opportunities reported by the majority of participants to constructively engage with their interests. This study suggests advocacy for children to have increased access to interest-based learning opportunities. The Developmental Assets approach, which includes a model for community development, provides school communities with a potential framework to understand, measure and respond to the well-being needs of students, as is required of schools by the Well-being for Success policy (Education Review Office, 2013).
\end{abstract}

\section{Research Paper}

\section{Keywords:}

child well-being, developmental assets, primary

\section{BACKGROUND}

Child well-being is a multi-faceted construct that varies in its meaning across cultures and disciplines (Aldgate, 2010). It is most easily understood through the term health, with the terms well-being and health often used synonymously (Durie, 1994). Health is defined in New Zealand by Te Whare Tapa Whā (Durie, 1994) which constructs health around taha tinana (physical well-being), taha hinengaro (mental and emotional well-being), taha whānau (social wellbeing) and taha wairua (spiritual well-being), all of which are located, for Māori, on the whenua (land), their place of belonging. Health and well-being are understood to exist on a positive continuum, linked to the idea of a 'good life' (Buchanan, 2000), in which individuals and collectives thrive (Seligman \& Csikszentmihalyi, 2000).

While child well-being has two measurement paradigms, both support the child's rights to have their voice heard and included on matters that affect them (Aldgate, 2010; United Nations, 1989). The child well-being indicators provide quantitative measures of child well-being that are used, for example, to guide the development of social policy (Ben-Arieh, 2010). Subjective child wellbeing research describes the other measurement paradigm. These studies have employed a variety of methodologies and have generated a large number of child well-being taxonomies (Dex \& Hollingworth, 2012). According to Dex and Hollingworth (2012), the overarching themes include feeling loved within significant relationships, having a quality home, school and community environment, and being physically and emotional healthy (see Table 1). Culture will determine what these themes look like. The well-being views of primary school-aged children are also included in the subjective child well-being studies published by Morgan (2010) and Fattore, Mason and Watson (2009), both of which are included in Table 1.

The Developmental Assets approach is an ecological, strengths-based and child-focused framework that conceptualises child well-being in terms of forty different Developmental Assets (Search Institute, 2012). Research has repeatedly shown that higher asset levels are associated with: a) greater achievement in school (Scales, Benson, Roehlkepartain, Sesma \& Van Dulmen, 2006); b) increased valuing of cultural diversity and satisfaction with life (Scales, 2014), and c) reduced risk of certain behaviours including alcohol abuse and violence (Benson \& Scales, 2009). Used in over sixty countries by over three million youth, and recently aligned with the international study of Health Behaviours in School-Aged Children, the validity and efficacy of the assets approach is well-established (Scales, 2014). 
Table 1

Key Components of Subjective Child Wellbeing

\begin{tabular}{|c|c|c|}
\hline MORGAN (2010) & FATTORE, MASON \& WATSON (2009) & DEX \& HOLLINGWORTH (2012) \\
\hline $\begin{array}{l}\text { Being healthy }(44 \%) \\
\text { Feeling loved }(24 \%) \\
\text { Having a home }(23 \%) \\
\text { Having fun }(21 \%) \\
\text { Feeling happy }(19 \%) \\
\text { Being cared for }(17 \%) \\
\text { Being safe }(17 \%) \\
\text { Having a family }(14 \%) \\
\text { Having friends }(14 \%) \\
\text { Being supported }(11 \%)\end{array}$ & $\begin{array}{l}\text { - Main themes: } \\
\text { - Significant relationships } \\
\text { - Emotional life } \\
\text { - Central themes: } \\
\text { - Positive sense of self } \\
\text { - Agency } \\
\text { - Security } \\
\text { - General themes: } \\
\text { - Physical environment } \\
\text { - Material \& economic resources } \\
\text { - Physical health } \\
\text { - Activities } \\
\text { - Social responsibilities } \\
\text { - Adversity }\end{array}$ & $\begin{array}{l}\text { - Quality of relationships: } \\
\text { - With parents, friends, family, } \\
\text { teachers \& pets } \\
\text { - Including qualities of love, } \\
\text { acceptance, care, support, } \\
\text { togetherness, respect, praise, } \\
\text { fairness, listening } \\
\text { - Self and freedoms: } \\
\text { - Health; food \& exercise } \\
\text { - Education; achievement \& aspirations } \\
\text { - Choices; use of time, possessions, } \\
\text { IT, freedom \& responsibility, sports } \\
\text { \& outdoor activities } \\
\text { - Quality of Environment: } \\
\text { - Home, school, neighbourhood } \\
\text { - The importance of having fun } \\
\text { and play at home and in the } \\
\text { neighbourhood, particularly for } \\
\text { primary school-aged children }\end{array}$ \\
\hline
\end{tabular}

The recent development of a spiritual axis, defined as awareness of self and the world, connection and belonging to others, and having a life of meaning and contribution (Benson, Scales, Syvertsen \& Roehlkepartain, 2012) further aligns the Developmental Assets approach with Te Whare Tapa Whā (Durie, 1994), which underpins the Health and Physical Education section of the New Zealand Curriculum (Ministry of Education, 2007). This study was an initial exploration of the assets approach within the New Zealand context.

\section{METHOD}

Ethics approval for this study was obtained from Massey University Human Ethics Committee (MUHEC). Support was gained from the principal and the board of trustees of a local primary school to include all Year 5 and Year 6 students attending this school in the study. An information sheet was then sent to parents including an opt-out form. Only one parent elected to return the opt-out form.

The study employed a mixed method design which involved semi-structured well-being discussions and administration of the Developmental Assets ProfilePreteen questionnaire (DAP-P). The semi-structured well-being discussions, held in either small groups or one-to-one, used an adapted version of Fattore, Mason and Watson's (2007) interview guide (see Table 2). The well-being views of 81 participants (41 female and 40 male) were recorded. The DAP-P, which contained 58 questions relating to the 40 Developmental Assets, was read out loud by the researcher to whole classes. It was completed by 132 participants ( 65 female and 67 male). The average age of participants was 10 years old.

A data-driven thematic analysis was completed on the child well-being discussions (Braun \& Clarke,

Table 2

The Interview Guide

\begin{tabular}{|l|l|}
\hline INTERVIEW QUESTIONS & INTERVIEW QUESTIONS \\
\hline Summary questions & $\begin{array}{l}\text { 1. What does well-being or 'being well', mean or feel like to you? } \\
\text { 2. Tell me about a time in your life when things were going really }\end{array}$ \\
\hline $\begin{array}{l}\text { Components of well-being } \\
\text { questions }\end{array}$ & $\begin{array}{l}\text { 3. Tell me about people that make you feel well. } \\
\text { 4. Tell me about places that make you feel well. } \\
\text { 5. Tell me about things that make you feel well. }\end{array}$ \\
\hline
\end{tabular}


2006). Previous research was used to guide initial interpretation the data, leading to the identification of 21 themes (Miles \& Huberman, 1994). Thematic maps were used along with thematic frequency data and co-occurrence rates to identify three main themes and five subordinate themes. The main theme of interests included discussion of music, art, literacy, dance, technology, nature, sports and toys. Inter-rater reliability between the researcher and a fellow graduate student was $86.5 \%$ (Miles \& Huberman, 1994).

The DAP-P data was entered into a pre-formatted Excel worksheet provided by the Search Institute. This produced a total assets score and eight individual asset category scores. The constructive use of time asset category was the lowest scoring asset category, with the positive values and positive identity asset categories also scoring in the low and vulnerable range. All other asset categories including social competencies, commitment to learning, boundaries and expectations, empowerment and support scored in the moderately high level.

The two data sets were integrated through a ranking process. The thematic data was ranked according to frequency and the assets data relative to strength of response.

\section{FINDINGS}

The thematic analysis gave rise to eight interconnected well-being themes (see Figure 1). The three main themes were relationships, emotional health and interests. Their interconnection is illustrated in the diagram by the three overlapping circles.

The subordinate themes of safety, values, special events and accomplishment provided independent and inter-related contributions to well-being. All themes co-occurred with the environmental theme, visually represented in the diagram by the outer environmental circle.

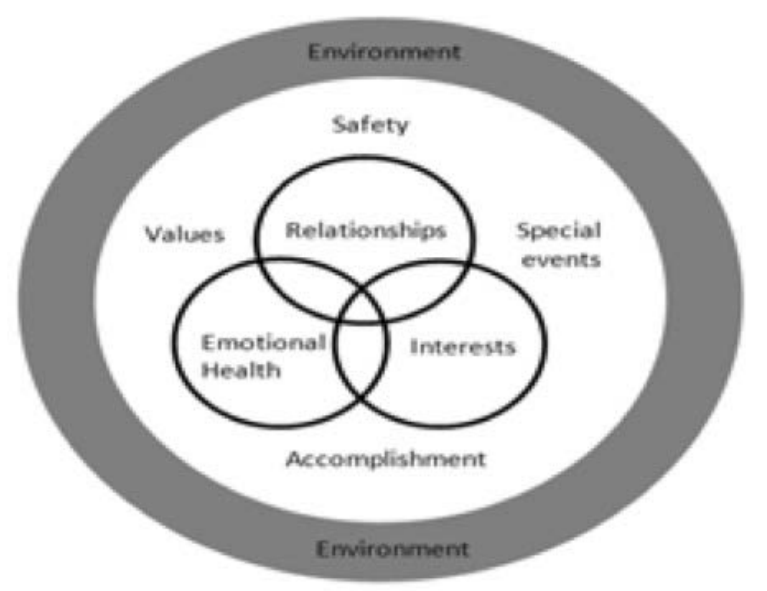

Figure 1: Child well-being themes.
The main themes of relationships and emotional life have been well-established in the literature (Fattore et al., 2009; McAuley \& Rose, 2014). The identification of interests as a main well-being theme may reflect age-specific importance to local primary school-aged children, an assertion supported by Chen (2011). The extract below illustrates the inter-relationship between the key themes:

Researcher: Tell me about people that make you feel well?

Participant: My family and my best cousin.

Researcher: What makes her your best cousin?

Participant: We are the same age and like the same stuff and we're nice to each other and happy.

Table 3 integrates the thematic data and developmental assets data. There is a semantic overlap between the two most-frequently discussed well-being themes of relationships and emotional health, and the two strongest asset categories of support, and boundaries and expectations, with the latter providing for the former (Scales, 2014). This implies that the Developmental Assets approach could be applied to develop the asset categories of support, and boundaries and expectations, which for vulnerable youth may facilitate enhancement of relationships and emotional health. The most significant disparity between the two data sets was in the main well-being theme of interests and the weakest asset category of constructive use of time, in which the majority of children reported limited opportunities to engage with their interests outside of school. This finding argues for parents, teachers, practitioners and school leaders to facilitate increased access to interestbased learning opportunities for all students, especially in light of the commitment to learning asset category being the third strongest asset category. 
Table 3

Integration of the Thematic Child Well-Being Data and Assets Data

\begin{tabular}{|c|c|c|c|}
\hline RANK & $\begin{array}{l}\text { CHILD WELL-BEING VIEWS } \\
\text { Thematic Frequency }\end{array}$ & RANK & $\begin{array}{l}\text { DEVELOPMENTAL ASSETS CATEGORIES } \\
\text { Asset Strength }\end{array}$ \\
\hline 1 & $\begin{array}{l}\text { Emotional Health } \\
\text { Positive emotions \& self-esteem }\end{array}$ & 1 & $\begin{array}{l}\text { Support } \\
\text { Being loved \& cared for }\end{array}$ \\
\hline 2 & $\begin{array}{l}\text { Relationships } \\
\text { Key relationships \& their qualities \& agency }\end{array}$ & 2 & $\begin{array}{l}\text { Boundaries and Expectations } \\
\text { Clear expectations, consistent consequences }\end{array}$ \\
\hline 3 & $\begin{array}{l}\text { Interests } \\
\text { Activities of choice }\end{array}$ & 3 & $\begin{array}{l}\text { Commitment to Learning } \\
\text { Life-long learning \& believing in their capabilities }\end{array}$ \\
\hline 4 & $\begin{array}{l}\text { Special Events } \\
\text { Personal \& social celebrations }\end{array}$ & 4 & $\begin{array}{l}\text { Empowerment } \\
\text { Feeling valued and safe }\end{array}$ \\
\hline 5 & $\begin{array}{l}\text { Safety } \\
\text { Basic physiological \& safety needs }\end{array}$ & 5 & $\begin{array}{l}\text { Social Competency } \\
\text { Effective interaction, decision-making \& coping }\end{array}$ \\
\hline 6 & $\begin{array}{l}\text { Values } \\
\text { Positive values }\end{array}$ & 6 & $\begin{array}{l}\text { Positive Values } \\
\text { Guiding values }\end{array}$ \\
\hline 7 & $\begin{array}{l}\text { Accomplishment } \\
\text { The joy of learning \& attainment }\end{array}$ & 7 & $\begin{array}{l}\text { Positive Identity } \\
\text { Self-esteem \& agency }\end{array}$ \\
\hline 8 & $\begin{array}{l}\text { Environment } \\
\text { The ecological contexts of well-being }\end{array}$ & 8 & $\begin{array}{l}\text { Constructive Use of Time } \\
\text { Opportunities to develop new interests outside of } \\
\text { school }\end{array}$ \\
\hline
\end{tabular}

\section{IMPLICATIONS}

The Education Review Office (ERO, 2013) asks all schools to measure and respond to the well-being needs of students. This request is based on the belief that, by developing a system to strengthen the well-being all children, we will be better-able to protect our most vulnerable children, promoting their well-being of and positive educational outcomes (Kahn, 2010). The recently published Well-being for Success Pilot Study Update (ERO, 2015) highlighted the continued need to develop a greater understanding of children's well-being views and the variability amongst schools in their response to child well-being needs. The availability of the research-based Developmental Assets approach, with its questionnaire designed to collate the child's voice, model of community development and measurement framework which provides for ongoing measures of treatment efficacy, may be used by school communities to develop a clearer understanding of child well-being needs from the child's perspective, and provide a measured response.

\section{OPPORTUNTIES FOR FUTURE RESEARCH}

Future research on either subjective child well-being or the Developmental Assets approach may look to analyse the data according to the dimensions of Te Whare Tapa Whā (Durie, 1994) or Te Wheke (Pere, 1997). Once the Developmental Assets framework has incorporated the newly-developed spiritual axis, future research would include a cultural analysis completed by Māori, and a pilot study to assess the efficacy of the assets framework.

\section{CONCLUSION}

A significant opportunity has recently emerged for school communities to develop local child well-being initiatives (ERO, 2013). The current study identifies one research-based framework that may facilitate an effective and efficient response. This study suggests the importance of increasing childrens' opportunities to constructively use their time and engage in interestbased learning opportunities as a pathway to enhancing the well-being of primary school-aged children. This has relevance to parents, teachers and practitioners, all of whom make decisions on a daily basis that influence child well-being. To affect positive change for the larger school community depends on our ability to collaborate, release traditional role boundaries (Idol, Paolucci-Whitcomb \& Nevin, 1995) and work together to access and utilise the available resources.

\section{REFERENCES}

Aldgate, J. (2010). Child well-being, child development and family life. In C. McAuley \& W. Rose (Eds.), Child well-being: Understanding children's lives (pp. 21-38). London: Jessica Kingsley Publishers.

Ben-Arieh, A. (2010). Developing indicators for child well-being in a changing context. In C. McAuley \& W. Rose (Eds.), Child well-being (pp. 129-142). London: Jessica Kingsley Publishers. 
Benson, P., \& Scales, P. (2009). Positive youth development and the prevention of youth aggression and violence. International Journal of Developmental Science, 3(3), 218-234. doi: 10.3233/DEV-2009-3302.

Benson, P., Scales, P., Syvertsen, A., \& Roehlkepartain, E. (2012). Is youth spiritual development a universal developmental process? An international exploration. The Journal of Positive Psychology, 7(6), 453-470. doi: 10.1080/17439760.2012.732102.

Braun, V., \& Clarke, V. (2006). Using thematic analysis in psychology. Qualitative research in psychology, 3(2), 77-101. doi: 10.1191/1478088706qp063oa.

Buchanan, D. (2000). An ethic for health promotion: Rethinking the sources of human well-being. Oxford: University Press Oxford.

Chen, Y. (2011). Narrative identity and well-being from middle childhood to late adolescence: A developmental, cross-cultural perspective. (Unpublished Doctoral thesis, University of Otago, Dunedin, New Zealand).

Dex, S., \& Hollingworth, K. (2012). Children's and young people's voices on their well-being (Report No. 14). London: Childhood well-being research centre. Retrieved from:

http://www.cwrc.ac.uk/projects/documents/FINAL Dex_September_2012_Report_on_childrens voices_on_well-being_Working_Paper_No_14.pdf.

Durie, M. (1994). Whaiora: Māori health development. Auckland, New Zealand: Oxford University Press.

Education Review Office (2013). Well-being for success. Wellington, New Zealand: Author. Retrieved from: http://ero.govt.nz/Review-Process/Frameworks-andEvaluation-Indicators-for-ERO-Reviews/Well-beingIndicators-for-Schools.

Education Review Office (2015). Wellbeing for children's success at primary school. Wellington, NZ: Crown Copyright Education Evaluation Reports.

Fattore, T., Mason, J., \& Watson, E. (2009). When children are asked about their well-being: Towards a framework for guiding policy. Child Indicators Research, 2, 57-77. doi: 10.1007/s12187-0089025-3.

Idol, L., Paolucci-Whitcomb, P., \& Nevin, A. (1995). The collaborative consultation model. Journal of Educational and Psychological Consultation. 6 (4), 347-361.

Kahn, A. (2010). From child saving to child development? In S. Kamerman, P. S. \& A. Ben-Arieh
(Eds.), From child welfare to child well-being: An international perspective on knowledge in the service of policy making. Dordrecht: Springer.

McAuley, C., \& Rose, W. (2014). Children's social and emotional relationships and well-being: From the perspective of the child. In A. Ben-Arieh, I. Casas, I. Frønes \& J. Korbin (Eds.), Handbook of child wellbeing: Theories, methods and policies in global perspective (pp. 1865-1892). Dordrecht: Springer.

Miles, M., \& Huberman, A. (1994). Qualitative data analysis: An expanded sourcebook (2nd ed.). Newbury Park, CA: Sage Publications.

Ministry of Education (2007). New Zealand curiculum. Wellington, NZ: Author.

Morgan, R. (2010). Children on rights and responsibilities Retrieved from: http://www.ofsted.gov.uk/node/2420.

Pere, R. (1997) Te Wheke. A celebration of infinite wisdom. Wairoa, NZ: Ako Global.

Scales, P. (2014). Developmental assets and the promotion of well-being in middle childhood. In A. Ben-Arieh, F. Cassas, I. Frones \& J. Korbin (Eds.), Handbook of child well-being (pp. 1649-1678). Netherlands: Springer.

Scales, P., Benson, P., Roehlkepartain, E., Sesma Jr, A., \& van Dulmen, M. (2006). The role of developmental assets in predicting academic achievement: A longitudinal study. Journal of Adolescence, 29(5), 691-708. doi: 10.1016/j.adolenscence.2005.09.001.

Search Institute (2012). Developmental assets profile. Minneapolis, USA: Author.

Seligman, M. M., \& Csikszentmihalyi, M. (2000). Positive psychology: An introduction. Retrieved from: http://www.bdp-gus.de/gus.de/gus/positivepsychologie-aufruf-2000.pdf.

United Nations (1989). United Nations convention on the rights of the child. Geneva: Author. Retrieved from: http://childrenandyouthprogramme.info/pdfs/ pdfs_ uncrc/uncrc_summary_version.pdf.

Acknowledgment and thanks is given to Search Institute, who provided free access to the Developmental Assets framework; to Associate Professor Jill Bevan-Brown and Dr Hal Jackson who guided and supported me throughout this Master's thesis; to Terence Edwards, who in the absence of my thesis supervisors advised me on how to write an article; to the school, staff and pupils involved in the study who so kindly gave me their time and thoughts; and to my family, friends and work colleagues who I am so grateful to have in my life. 
AUTHOR PROFILE

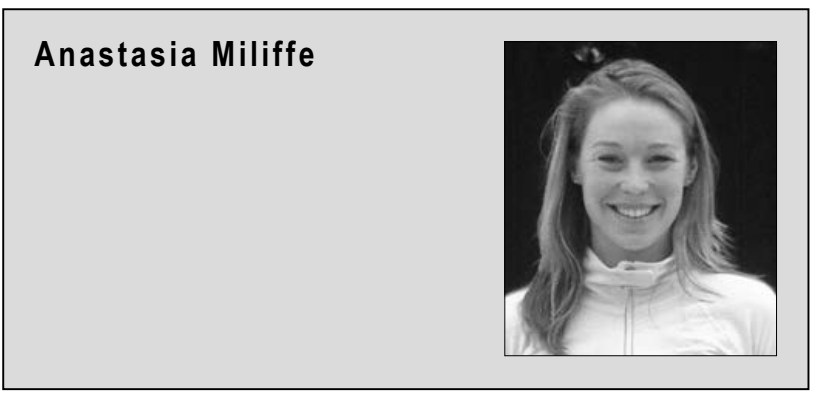

Anastasia Miliffe has a Masters in Educational Psychology from Massey University. Her previous research topics have included specific reading difficulties and the efficacy of intervention programmes for struggling readers. She is currently completing her Educational Psychology internship through Massey University and is employed by the Ministry of Education in Dunedin.

Email: ana.miliffe@education.govt.nz 